\title{
ECONOMIC ORGANIZATION OF KHUSRA COMMUNITY OF PAKISTAN
}

\author{
Fahd Zulfiqar \\ Lecturer, Department of Development Studies, \\ Pakistan Institute of Development Economics \\ fahd@pide.org.pk \\ Ikram Badshah \\ Assistant Professor, Department of Anthropology, \\ Quaid-i-Azam University, Islamabad \\ ikram@qau.edu.pk
}

\begin{abstract}
In the context of Pakistan, existing literature on male-female transgender persons has majorly focused on health-related issues such as Sexually Transmitted Diseases (STDs) and HIV/AIDS. Very few research studies have gone beyond and explored the socio-cultural aspects of khusra lives and their socio-economic organization. The objective of current research is to focus on the economic organization of khusra community using qualitative research as the research strategy. For the purpose of current research, data was collected from 4 locales; Mansehra City, City Kasur, Rawalpindi and Kot Radha Kishan. In-depth interviews were conducted with sampled respondents from sampled sub-locales of 4 main locales. The findings highlight that set against the backdrop of their lives categorized by structural violence, socio-economic discrimination, and ostracization, khusra community manages to integrate with the wider population through various forms of survival strategies, which for the current study are grouped under economic organization. These forms of survival strategies or livelihood options were the focus of the current research. The data elicited through individual and group interviews highlight dhinga/tola bazar, bidhaee and taarhi. dance functions, and prostitution as the forms of economic organization. These forms of economic organization do not guarantee social security and are transient in nature. Furthermore, the narratives also detail various forms of risks and vulnerabilities (socio-economic and health-related), respondents face while earning through prostitution and other forms of economic organization.
\end{abstract}

Keywords: Economic Organization Ethnography, Khusra, and Pakistan

\section{INTRODUCTION}

Pakistan, despite historically and culturally being a homosocial and homoaffectionalist society, is asymptotic towards discrimination and ostracization of 'off the track', 'sinfully unconventional' or 'deviant' (Caceres et. al., 2008) individuals of the society. Particularly in South Asia, for people of third gender identity (commonly known as hijra or khusra), societal intolerance and violence is attributed to strict moral, religious, and legal codes. According to Pakistan Penal Code, homosexual activities are punishable; moreover, strict social norms and religious statute further prohibit such sexual proclivities. With severe consequences to those men and women caught in non-marital sexual activities and prosecution against adultery and infidelity, the more accessible choice for unburdening compulsive sexual urges for men is to get into secretive sexual links with other boys or feminized men (Khan \& Khan, 2010). Among these feminized men are the khusras; the biological males who are raised as boys but show pronounced inclinations towards inhabiting attires and behaviors of women. Domestically sidelined, socially ridiculed and sexualized, and economically marginalized, khusras leave their native areas and join communes called Dera $^{i}$ where their presences are assured by following organized rituals and customs.

This research has covered certain aspects of the lives of individuals in these communes. The broader areas of thematic focus covered were the framework of their culture, socioeconomic organisation, socialization into socio-sexual environment, and sexual and economic exchanges. The attempt of this research is not to controversialize, sexualize or vulgarize the individuals in these 
communities, rather to confirm to the existing body of scholarship, which empirically exposits the health-related issues, seclusion, sexual abuse, and disempowerment of khusras and to humanize with their struggle for survival in the environment plagued with fear, threat, intimidation, and violence. Furthermore, this research has explored their options for survival and socio-sexual networks.

The significance of the current research is defined along two axis, methodological and theoretical. The methodological significance is due to in-depth data collected through narrative interviews. The first author lived with the community members, observed day-to-day activities and cross-checked the data by triangulation technique. The authors later analyzed data using thematic analysis as the approach and framework analysis as the technique, which entailed linear process of transcribing, indexing and coding, thematic charting, and theming and sub-theming. The theoretical significance of the study is outlined by the principle of inductivism in which contribution to theory is guaranteed by the collected and analyzed data. This study has not just described various forms of economic organization but also relational, spatial, communal, and cultural dynamics, therein.

\section{Socio-Economic Organization of Hijras in South Asian Context}

Islamic history unearths three classifications of people of third gender roles: eunuchs, mukhannat and hijras (Al-Haqq, 2010). Eunuchs were people born with male sexual organs and raised as boys but castrated. Through castration, they did not become females, rather adopted a 'no-gender' role, which means having no social and legal gender roles. The second classification of mukhannat includes people who are born with male sex organs and raised as boys, but showcase feminine behaviors. The term shows transgender and transvestite behaviors and does not show any particular sexual orientation. In Islamic history, they have been labeled as men with effeminate conducts. However, in medieval times they were referred to as men who played passive roles in sexual intercourse. Third classification of hijras includes people who are born with male sex organs and raised as boys, but after reaching the age of puberty they self-identify as women and start dressing and behaving like the opposite sex. More appropriately, after joining the highly structured clans of hijra communities they undergo castration process (which involves removal of both testicles and penis) voluntarily. Since hijras are culturally defined as women trapped in the bodies of men and because of their strong desires to inhabit the physical, sexual, and social roles of women, they are referred closest to the transgender experiences (Kuggle, 2010). In their attempt to look more feminine they inhabit certain female characteristics, which include adopting female names and dressing, and growing long hair.

Kuggle (2010) argues that in Muslim patriarchal societies where gender binaries as men and women taking legally sanctioned and socially normative gender roles are highly valued, a third gender or transgender experience could be seen as a threat to the socio-cultural fabrics. Since Muslims whether conservative or neo-traditionalists, regressive or progressive, backward or modernists try to reside into Quranic and Sunnah references for solutions of their personal and social issues, Kuggle (2010), also tries to explore some progressive and embracing referential evidences from Quran and Sunnah to accommodate transgender roles. The most dominant among these roles in Islamic history are those of mukhannath, who rather than socially referred as sexualized bodies were defined in terms of their 'speech, gesture, gait, and clothing'. Muslims were not socially secluding towards mukhannath as they recognize their (mukhannath) proclivities towards femininity as innate that must not be blamed. Islamic historians and commentators distinguish between Khilqi and Takallufi with fomer defined as a person who behaves effeminately due to inherent dispositions whereas the later due to self-driven interests and ulterior motives. In Islam, these are Takallufi who are blamed because their behaviors do not, express their personalized inclinations and innate dispositions. On contrary, mukhannath were given specific gender roles. They had access to private places of women where men were not allowed, and to public places where men dominated and women were not allowed. Some functioned as singers, entertainers, and comedians. Since society, in general, accepted the third gender role, hence mukhannath were not socially banished. But there have been instances, when as a result of working as mediators for heterosexual adulteries they have been banished by the Holy Prophet and much later by the rulers of Ummayad Empire years after the Holy Prophet's death. Particularly in Ummayad Empire, mukhannath were castrated as punishment for their immoral acts. There are different reasons and interpretations for this punishment. But according to al-Isfahani's version, the 
ruler was angry at the musicians and singers because his most favorite slave girl ignored him once to listen to man's singing voice. Due to jealousy, he ordered castration of not only that particular man, but also of mukhnnath involved in musical entertainment. Moreover, the stories circulated about involvement of mukhannath in facilitating romantic interactions between men and women, which was socially reprimanding, also ignited the agitation among rulers against mukhannath. The mukhannath response towards castration was sarcastically humorous and they agreed to it calling 'another circumcision'. After this punishment there are rare mentions of mukhannath in Medina and Macca, according to some scholars they were driven out.

In the South Asian context, hijra is defined as a third gender (Nanda, 1999; Abdullah et. al., 2012). Usually defined as an umbrella term for people performing third gender roles, hijras include intersex (hermaphrodites), transsexuals, transgenders, cross dressers, homosexuals and bisexuals (Abdullah et. al., 2012). The localized South Asian vernaculars are context specific, and the term hijra can be classified into zenana (cross dressing men who may or may not be castrated), khusra (feminized men who are usually castrated), nirban (feminized men who are necessarily castrated), and uqwi (feminized men who are not castrated) (Abdullah et. al., 2012).

Entry into the hijra communities is driven in the early childhoods by the gender ambiguousness that builds on with passing years. Additionally, the encounters with the hijras on various ceremonies urge feminized men to showcase their inner sense of self, gender, and identity by joining hijra communes (Nanda, 1999; Reddy, 2005; Abdullah, 2012). Hijra communes are divided into households. Each household is governed by the head called Guru. Under each Guru, 10 to 12 chelas (subordinates) work. In this hierarchical setup, strict moral and domestic codes of conduct are to be obligated by the hijras according to which they have to perform domestic chores, earn money, and financially contribute to the households, handover a significant chunk of the earnings to the Guru as a response of which Guru assures social security to chelas (Nanda, 1999; Reddy, 2006; Abdullah, 2012).

In the subcontinent, historically, societal positions of hijras were different. They used to be the active members of the state and court affairs and were appointed in the harems for serving the needs of wives of emperors and concubines, also in protecting them from forceful external interventions. Respected social roles of healers and social mediators were provided to them. In the previous decades, colonization, modernization, and urbanization have eroded their social roles and relegated them to informal institutional arrangements of entertainment (dance, music, and transsexual prostitution). Naqvi and Mujtatba (1997), while referring to the current status of hijras in Pakistan, elucidate two instances from political history of Pakistan. First, in 1960s when as a result of banning hijra activities they collected in front of Ayub Khan's house as a result of which the ban was annulled. Second, in 1990 election, a hijra candidate was selected to take part from Abbottabad for the first time in the political history of Pakistan. These instances of collective action and political participation are rare and in spite of the provision of Computerized National Identity Cards by Lahore High Court in 2010, and right to contest and take part in 2013 elections, nothing significant has been achieved yet to destigmatize the individuals in these communities. The reason for this being their nonconformist gender behaviors and their involvement in "notorious" activities of prostitution and drug use. Talking about prostitution there was a point of difference recorded between Sindhi zenana and Baluchi Buggas (a local vernacular for hijra in Balochistan) (Naqvi \& Mujtaba, 1997). To some of the respondents, hijras are not prostitutes, whereas zenanas are men with families and children who fake women attires and do dhanda (prostitution) for money. To others, hijras are most admired by men because of their beauty and relational commitment. This rare study explains reasons for marriages between hijras and heterosexual men. The historical reasons for hijras to marry men were to get hold over their possessions particularly men possessing donkey carts (a high valued and prized commodity), in some of the references men would marry hijras because hijras would provide their potential husbands the amounts required to buy donkey carts (Naqvi \& Mujtaba, 1997). Another reason explained was the high food in-take and hence greater sexual urge of men that could only be fulfilled by marrying a hijra. The study calls in the attention towards the importance of castration in the social uplift within hijra communities. For some, castration is an act of spiritual devotion. For those among hijras who castrate kill their nafs, which means sacrificing male sexual organs to get rid 
of sexual desires. It brings respect to hijras because they stake their lives as the emasculation process is intense and recuperating period is slow and dangerous (Naqvi and Mujtaba, 1997; Nanda, 1999).

In India, Pakistan and Bangladesh, in addition to bidhaee ${ }^{1}$ and bazaar tola ${ }^{2}$, hijras supplement their earnings through prostitution. Working as part-time or full-time prostitutes, hijras satisfy their sexual needs performing certain risky sexual acts just for extra cash (Khan et. al., 2009). Exchange of sex for money is constitutive of socio-economic organization of hijra communities. The commoditization and objectification of bodies for loveless short-term sexual encounters constitutes an important source of meeting functional needs of hijras in South Asia. But for some (particularly more feminine), long-term relationships with men who they call their husband lovers is an ideal situation for emotional, sexual, and financial satisfaction (Khan et al. 2009). Such commonalities are drawn by Nanda (1999) through her case studies on hijras of India. Among the most highly valued of their relationships is the marriage with the men who they call their 'husbands'. In Indian culture, marriage elates the societal status of women. And since hijras self-concept perceive themselves as women, hence finding a man, getting emotionally and physically involved with him, and ministering to his needs and wants reaffirms femininity in them. Nanda's respondents share reciprocal relationships with their husbands, apart from financial support their husbands supported them emotionally and psychologically as well. Hijras, too, share their incomes earned through bidhaee, and prostitution. The expressions of love for husbands, observed by Nanda, are fairly dramatic and hugely influenced by the Hindi films in which romantic love and feelings of jealously coalesce on the verge of melodrama. Among these expressions are also included gift exchanges.

\section{LOCALES AND METHODOLOGY}

Four geographical locales of Rawalpindi, City Kasur, Mansehra and Kot Radha Kishan were selected for research. Four Rawalpindi locales are urban centers, which have undergone the most rapid urbanization, industrialization, commercialization, and economic development, although, this development has occurred spatially and has not trickled down indiscriminately. With booming foreign and local monetary influx into the construction and commercial sectors of the city, increasing consumptive nature of the society, and rising proclivities towards the postmodern commodities, the urban center is becoming more monetized. Moreover, social and income inequalities have increased, which can be observed with high inflation inflicting the already-poor societal segments, mounting poverty, and informal settlements around the outskirts of most of the commercial areas of Rawalpindi. Income inequality, in particular, has increased in relation to socio-economic characteristics (age, gender, race, and ethnicity). The impact of this development at the cost of equality innately provides strong locale settings for the study on hijras. Rawalpindi is the most thickly populated with hijras where they reside in the dungeon dark one-two room settlements of incomplete or under-constructed buildings.

Both Kasur and Kot Radha Kishan have been selected purposively because of the locales' strong cultural and historical references of transgender communities. In comparison to Rawalpindi, Kasur and Kot Radha Kishan are less densely populated, particularly the latter being a town has a more homogenous and less mobile population. The social interactions are intimate, and social control is regulated by the social institutions comprising of union councils (political institution), police (institution of formal social control), and panchayat (in part cultural, in part institution of social control). Mansehra city is part of Khyber Pakhtunkhwa region of Pakistan. The focus of this research was on Mansehra city, which is the administrative capital of Mansehra district.

Babu Building (Mansehra) and Handaal Chowk (Kot Radha Kishan) provided rich locale settings for research on hijra communes because these locales are homes to the poorest of the community members. Babu Building is a dilapidated three-storey building with roughly cemented walls and coarse staircase. Each storey comprises four to five small rooms. The room, which I rented during my research was on the second storey, the door to which was coloured green and made of tin. My room was in between the other two rooms rented by two khusras. The monthly rent was 3000 Pakistani Rupees. The rents varied in each locale. Usually the deras located at or near commercial

\footnotetext{
${ }^{1}$ Collection of money at marriages and child births through dance performances.

${ }^{2}$ Collection of money doing beggary on the roads and market places.
} 
sectors or residential areas (near Mansehra Main Chowk in Mansehra, Darzi Mohallah in Kot Radha Kishan, Raja Sultan Market and Dhoke Kala Khan in Rawalpindi and Haji Fareed Road in city Kasur) were higher than those located at non-commercial and non-residential areas. Deras of Pirwadhai in Rawalpindi, though located in residential areas were not costly because of poor people residing in the rented rooms of poor physical infrastructure. Handaal Chowk is situated near railway station and Babu Building near a number of car mechanic shops and truck drivers' stopover points providing a variety of clients to khusras for sex-for-money exchanges. The respondents from Pirwadhai, also, responded of most of their clients coming from Pirwadhai Adda (bus-stand) in Rawalpindi. The deras at Handaal Chowk were one or two room settlements, the one where I lived was a single room dera, which I shared with one of the respondents during initial and final research.

The dera at Haji Fareed Road (City Kasur) where I stayed was a double storey settlement, the walls of which were painted pink. Unlike other deras from other locales, this one had an attached bathroom. I shared a room with one of the respondents in the upper storey and covered other deras in the near vicinity during initial and final research. The deras of Kot Murad Khan (City Kasur) were located in a narrow street near a very old tree to which community feels emotionally connected with.

The nature of the study was such that data related to themes such as early lives of respondents, societal perceptions towards them, economic organization and their sexual settings or networks cannot be reliably elicited without being part of the community. Moreover, for understanding discourses of community's language, rituals, ceremonial activities, customs and social structures, it was equally important to live with the community. Initial research was conducted in all the locales. The main objectives of this research were to initially conduct observational studies and build rapport, and then to frame topic/interview guide, and set the social contexts.

A type of non-probability sampling is the snowball, which is highly effective in accessing and listing the 'hard to reach populations', 'classes of deviance' and for sensitive research domains (Berg, 2001). Hence, combinations of peer and snowball were most effective in targeting the hard to reach communities of khusra. This research used a phased approach (Gaskell, 2000) in which during first phase (initial research) interviews and focus groups were conducted. After having gathered and analyzed data from the first phase, the second phase focussed on those respondents, covered those research areas and categories, which were more interesting and relevant to the research. Hence initial research was crucial for final field visits and final analysis.

A total number of thirty-three in-depth interviews were conducted in the final research with maximum respondents interviewed from Rawalpindi and minimum from Kasur. The decision on the number of respondents interviewed from each locale was dependent on the number of sub-locales included from each of the main locales and on how much a respondent is contributing towards the research. Total number of nirban (castrated khusras) and uqwi (uncastrated khusras) respondents were 4 and 29 respectively. Total number of nirban respondents who enlarged breasts through silicone surgery were 2, whereas total number of nirban respondents injecting estrogen (female hormones) through medicine and/or injections were 2. Total number of uqwi respondents injecting estrogen (female hormones) through medicine and/or injections was 8 .

Individual interviews such as Interview guides and narrative interviews and group interviews such as focus group discussions were conducted with the respondents. Preliminary observational studies, and rapport building with the respondents were instrumental in including diverse research areas to the interview guide and excluding the few existing ones either for conceptual reasons or because the respondents had little to respond about them. I had to revisit and modify topic guide thrice during the progression of this research because the research areas, which were important for the respondents of one locale were less important for another locale. Topic guide was used flexibly with other forms of data to explore social phenomena/reality. For this reason, naturally occurring data through participant observation was noted down in a diary.

For this research, the first author introduced himself to the study subjects as a researcher interested in the lives of male-female transgender persons. Key informants proved to be the most conducive intermediary between me and the study subjects. With the help of key informants and rapport building, the observational studies, which in the initial research design were tentatively planned as noncontrolled and nonparticipatory turned into noncontrolled and participatory. I was 
perceived as kothi or moorat (a feminine man) by khusra communes, which further helped me in gaining access to the field sites and to observe their lives in detail. Often I heard, during focus groups, one zenana saying to another, "Kachiyan kalama na khut, ay asa di cheesi shoormi hy." ("Don't tell a lie, she is our beautiful sister.") and "Shoormiyan naal kachi ni ay." ("Sisters don't hate each other."). Shoormi in their Farsi language means sister. They consider me their sister and telling a lie to and hiding things from sisters is disallowed in the community.

Thematic analysis was used to analyze data (Ritchie and Lewis, 2003). For thematic analysis, thematic framework was constructed. In order to construct thematic framework, all the field notes, and transcribed data from recordings was segmented, initially indexed and then coded, categorized and sub-categorized, themed and sub-themed, and structured under suitable categories.

\section{RESULTS AND DISCUSSION Dhingaltola bazaar}

One of the very old ways to earn for hijra community is through dhinga or tola bazaar (tola means a group of people and bazaar means market). A group of zenanas in sangat (group) visit pre-allocated areas asking for alms from passersby at traffic signals or from shopkeepers. The areas include busy markets, commercial zones, thickly populated residential areas and traffic signals. The locales of Rawalpindi (included in this research) are divided amongst khusras (from similar or other locales) for dhinga. The respondents from Banni Chowk covered Dhoke Chaudriyan and Bakra Mandi (locales of this research), Gulistan Colony, and Morgah for a month. In the same month the respondents from Pirwadhai covered Banni Chowk and Dhoke Kala Khan (locales of this research), Khanna Pul and Kali Tainki. It would be pre-decided between the khusras of Banni and Pirwadhai to cover areas not similar to each other for a specified period of time (a month usually). The reason of not sharing similar locales is to provide a more equal opportunity to earn from most to least rewarding locales.

It was observed through fieldwork that the earnings from more commercial areas such as Commercial Market, Banni and Bakra Mandi were greater than less commercial (Dhoke Kala Khan and Raja Sultan Market) areas. In Kasur, khusray from Khusharh Galli did not allow the zenanay from Haji Fareed Road to dhinga in their locale without permission. Often during fieldwork, the first author witnessed the respondents from Khusharh Galli locking one or two zenana(y) from Haji Fareed Road as captive(s) for roaming for dhinga without their permission. Then the guru of the captives will seek for mercy from their ancestral rich khusras, they will request to free their chelas. Only after new set of rules and negotiations the captives would be released. In Mansehra the earnings from more commercial and thickly populated areas (Cheriyaan Bazar and Dandi Mohallah) were higher than the less commercial and sparsely populated areas (Babu Building). Additionally, there were small outcity areas, informal settlements and villages which the respondents preferred visiting over mainstream locales due to the fear of being recognized by and exposed to family. The amounts earned out of dhinga were very low rarely exceeding one or two or five rupee coins (theepay) which after having earned were collected in a money box. The box is broken towards the end of the month or after two months. The coins are exchanged by rupee notes from shopkeepers to divide equally amongst the khusras usually residing in a dera. To Parvati ${ }^{\mathrm{ii}}$ dhinga can be rewarding if a khusra is skillful in convincing people of her problems. Usually females are more kind than males; they can be easily tricked for more money.

Parvati: "Females can be tricked easily; they are more kind than men. Men are usually unkind. They bully us, abuse us with dirty language, engage in physical fights with us if we retaliate to their foul language. I will not hide from you, some men do not open their wallets until we show them our body parts, few offer us money in exchange for intercourse."

Similarly, other respondents stated:

Masoom: “. . . Yesterday I returned home empty handed. Nobody wants to see us begging and roaming at their door steps. Often we ask for work other than dhinga, toli, paisha. Few agree but offer less money, seven thousand, eight thousand. [We] cannot survive with too little. Current situations are really gross." 
Saeeda: “. . . We go and earn fifty from somewhere, hundred or two hundred from another place. Like other people, our daily expenditures are somewhere between eight hundred and one thousand, difficult to earn this much. . Temporary earning (hawae rozi)."

Pooja: "There are days when I have to go home empty handed and whatever in pocket is spent also."

These are the respondents whom main source of income was dhinga. Parvati brings in the practical resistances to earn through dhinga. She speaks of men obstructing and denigrating her when she is out for dhinga, women, to her, can be tricked whereas men agree to pay only after sexual favors. Masoom despite wanting to change her mode of earning from dhinga to less condescending ways, but the amounts offered to her are too less to fund her expansive family responsibilities and dera lives. The remaining quotes are more explanatory of the impermanent nature of their living with no real stability to their earnings.

\section{Bidhaee and taarhi}

Bidhaee is often said on occasions of happiness as a congratulatory expression. For khusras across South Asia bidhaee is the occupational option in which khusras in groups visit a house on the birth of a newly born baby or a newly married couple. Nanda (1999) in her study on Indian hijras finds bidhaee as the most traditional occupation depicting a sangat (collection) of hijras of a specific area who mark with a chalk at the doors of newly born or newly weds. This sign is an indication for other khusras from another area to not to perform to those houses as those had already been covered or would be covered. Hindu society regards khusras for their spiritual prowess. Hindu society fears of raging a hijra as it can lead to hijra cursing the family that people believe is synonymous to bringing God's curse. Similarly, the hijras' blessings will bring prosperity. They are specially invited to shower blessings on the birth of newly born babies and wedding couples to bring happiness and bonanza to their future lives.

As an occupational option bidhaee is also famous within the community as taarhi. Taarhi is a Punjabi word, which means hand/palm clapping. Palm clapping is perhaps the most meaningful of the community's bodily expressions. Number of times the palms are struck against each other and the sound with which the palms are struck convey varied emotions in different contexts. Taarhi in bidhaee is tantamount to happiness in which khusras will be invited to shower their blessings at/after marriage celebrations and pre- and post- baby born ceremonies. Pooja, while eloquently marking the difference between taarhi and dhinga, revealed that in dhinga they are uninvited whereas in bidhaee they earn huge even in thousands because they are invited as guests. They are invited to dance, perform skits, make people happy and as a response paid well.

Qaseeda: "Yes, we visit that family and collect our bidhaee from them, "Bismillah sister, a baby boy is born to your house, Allah has bestowed you with a boy so give us our bidhaee" ("Bismillah baji apke ghar beta hua hai, Allah ne apko beta dia hai tou humay bidhaee tou do"). This is what we do and there are a few amongst us who don't have to bother much because they have children, we have to worry, we are the ones who have to go to houses, "Bismillah sister Allah will keep you happy" ("Bismillah baji Allah khush rakhay"). We have to say it at multiple doors."

Qaseeda presents a less promising picture of bidhaee. Unlike Pooja, her views seem to be more rooted in reality. Pooja brings in the dimension of 'invited guests' while expounding the differences between bidhaee and dhinga. Qaseeda, on the other hand, blurs the differences by saying in a rhythmic tone of a beggar asking for money from a baby's mother. It can be substantiated from fieldwork that with the passage of time the tradition of bidhaee has diminished as compared to dhinga.

In the more grounded locales of Kot Radha Kishan and Mansehra it was observed that, despite knowing, nobody from the community went for bidhaee due to minimal possibility of being well paid or even paid because people consider them uninvited. Qaseeda being a nirban and being disowned by her family after castration has to rely on any possible way to earn. It is widely observed in this research that uncastrated men (zenanay) are in better economic positions than castrated men 
(khusray) for the fact that zenanay can switch gender roles smoothly, haven't lost ties with their blood relations, are less feminine in their attires and appearances, and relatively more acceptable to the society.

Jorha is an Urdu word meaning clothes. In the context of Pakistani Pashtun weddings, jorha is a ceremony of displaying to the guests gifted stitched and unstitched clothes and other accessories from both the bride's and bridegroom's families. Items gifted are called warhi. A girl's warhi will include gifts from bridegroom's family and a boy's warhi will include gifts from bride's family. To these functions are invited one or at most three community members to perform on live musical instruments-dholak (double-sided drum), chimta (musical tongs), baja (trumpet), and harmonium. They take musicians along to play music. One respondent explained that jorha was different from vidhaee, which is an important part of wedding celebrations of KP whereas bidhaee is famous in Punjab. It is up to the discretion of invitees to pay (or not to pay) generously.

\section{Dance Functions}

Handaal Chowk in Kot Radha Kishan and Babu Building in Mansehra are homes to the poorest of khusra deras. With the current security threats, increase in urbanization and education, and growing western values, the traditional community occupations of jorhaa and bidhaee are diminishing. Dance performances may not always be rewarding as people disapprove of inviting khusras to their weddings for dance. As a result of decline in the market demand for their dance performances in weddings, they have expanded the range of the occasions and upgraded their dance skills for diverse audiences. They perform at melas, private functions and late night marriage gatherings, which are strictly for male audience.

Mela(s) (a sanskirit word meaning a cultural or religious festival or a fair) is (are) seasonal. Most of the mela festivals are celebrated in the vicinity areas of Kot Radha Kishan; the one attended was in Pattoki, which is one of the smaller cities of Kasur district at a distance of roughly 50 kilometers from Kot Radha Kishan. In Punjab, the festive season for mela is in winters from October till February each year. Mela is usually a cultural celebration integrating food stalls, music, dance performances, and entertainment of different sorts including palmistry, magic and puppet shows to death well stunts. Khusras fully clad and prepared to entertain the spectators, perform inside mot ka kuan (death well). The show starts with their performances. They, in a group of five or six, enter into the well, and dance on four songs. Tamashbeen (spectators) surround them from over the well and throw money over them as a gesture of appreciation, few vagabonds or rowdies lash coins to mock and hurt them. After finishing performances, they wait for the bell ringing, which signals time to leave the well. They climb the ladder up to come out, stand on a wooden bench waiting for the next round of performances. In the meantime, they touch up make up, rehearse for steps and drink lots of water. Cyclist finishes his performance and they climb down the ladder to dance again. There are usually three rounds of performances. The amounts they earn are the money thrown by the spectators, which to my amazement was in thousands in most of the cases. After performances, they enjoy with their chamkaas (regular male friends), those interested in prostitution search for suitable clients which is another source of earning and of those who bring their giryas (lovers) along make them spend a lot of money. Traditionally hijra groups take miraasi (musicians) to the functions. In Kasur, few respondents emphasized on the importance of live music and talked at length about the skills of synchronizing dance movements with the live musical beats, though most seemed less interested on performing to live music. The reason is that the greater the number of people taken along the more the division of earned money.

Looking beautiful at a mela is also essential as it provides them with multiple socializing opportunities. Many a times during fieldwork, it was heard khusras wishing to find a sareela (the best looking man) at a mela and since it can be lucrative for those interested in prostitution, so they want to look at their best. Those who have enlarged their chests look more feminine than those who haven't. There is quite a possibility of the earnings of less feminine looking being slashed by the more feminine ones. So in order to look more feminine they fill their chest area with doubled balloons filled with water. The pronounced chest area looks like a female chest with large breasts. Emulating femininity is priced high as most feminine looking receive more male attention and hence extract more money. One respondent who is famous for skillful dance, complained of men who prefer beauty 
over talent. To her, men should pay for delicate dance and femininity not for chitti chamrhi (white skin). Dance training is not necessarily elementary as most are fond of dancing since childhood and by the time they join dera they are prepared to perform at functions. All they need to learn though are mudra (movements of combination(s) of index, middle, ring, and little fingers with thumbs in classical dance), facial expressions and feet movements. Few in Rawalpindi and Mansehra learnt initials of Pashto and Sindhi dance from their gurus as learning these ethnic dance forms require a different skill set of rhythmic sense and signature dance moves. The songs are mostly famous Pakistani Punjabi and Bollywood songs, old Punjabi songs sung by Noor Jehan (famous Pakistani singer) are the hot favorites. The dance performances observed during fieldwork were suggestive and seductive, the need of which was highlighted by one of the respondents as:

Nisho: "It is liberating, I feel special and precious. All spectators (tamashbeen) admire me and my dance, I race their pulses, I make them go mad, I can do whatever I want to without allowing any man to do with me anything against my will. Is not it liberating! Then I enjoy dancing, going to melas, meeting [milli julli daya] friends, just enjoy it a lot."

The spectators are married and unmarried, young and old, drunk and unfrank men. Alcohol intake is common. Women are not part of such gatherings. Men want to do things they cannot do in the presence of their female members. They want to be entertained and shower hundreds and thousands of rupees on their favorite dancers. According to one respondent, men want to have shugal (fun) and if dealt tactfully they can throw their golden chains and even wallets on us. It was observed once in a private party in Mansehra, where a man emptied his entire wallet on a khusra. The trick is to keep a sharp eye contact with a man who seems to be the most interested, dance closer to him, pass him tempting smiles, and make special dance moves (bending body down and moving hips round, placing middle finger of a right hand on a cleavage and slipping down to lower torso, biting lower lip with teeth, and jerking head right and left to sway long hair).

Winters are not considered very productive for the khusras, they try to be part of most of the functions they can before winters become unendurably chilly. Functions tend to decrease so are the earning options in colder regions of Pakistan. Likewise, in Mansehra where temperature drops considerably during winters, khusras migrate to tropical areas looking for earning options. Just like weathers, their earnings are seasonal because festivals and functions are seasonal.

\section{Prostitution}

Nanda (1999) and Reddy (2005) observe prostitution as the most viable way for the hijras to earn a living. Poverty seems to be the only reason for male-female transgender persons to prostitute. This research observes that khusras are socialized into such settings that despite having other occupational choices they could not help resorting to prostitution. There are reasons to this. Firstly, sexuality works as a catalyst for many involved in flesh trade. Secondly, the quest to earn easy money. Thirdly, internalizing the fact that their bodies are sexual objects to be commoditized. Fourthly, helplessness: few helpless due to sexual urges and most due to economic hardships. And lastly, intimacy and quest for love.

Pooja: "Reason is that they don't like going outside a lot. They prefer to stay at dera, whoever comes, in what number comes they adjust all. They find no reason to roam around for money when they can earn staying at dera. . . . They don't leave whoever comes, they don't let anyone go without money, from beautiful to ugly, from white to dark . . . Money is crucial, it has to be there. They say yes to money. They put forward their price demand, if agreed then fine if don't then, "Go away" ("karay kara")."

Sassi: "They are not that helpless. They are but their problems can be no different from ours. They fear from hard work. What helplessness! It is tough for them to leave their cozy beds and earn through hard work when there is freezing cold outside. They prefer staying at deras, calling in five customers (chaamkay), and receiving one thousand in an hour, when this is an option then why to work too hard. They are scared of putting in effort ("dardiyaan ae khawariaan toon")." 
Nargis: "Few khusras prefer it over other sources of income, it is fast, relatively easier, and quick money."

Despite the fact that all the respondents in this research had engaged in sex-for-money exchanges, prostitution is stigmatized and disdained even within the community. Initial and final research at Kot Radha Kishan was conducted in winters and Sassi's opinions about her most beloved chela had hardly changed over almost a year time period. Kot Radha Kishan is moderately cold in winters; hence many khusras from KP, Sindh, and other cities of Punjab flock to make a living out of dance at functions and festivals of Kot Radha Kishan. Sassi's comments about her chela of not leaving a 'cozy bed' and 'freezing cold outside' signify that her chela despite having an option of earning through hard work opts to earn through shortcuts. Her claim of five men entertained in an hour seems a little too stretched, however, it was observed in detail through fieldwork that three-four clients can be entertained in an hour. The amount of one thousand for five clients (two hundred from each) is more or less similar when compared to the amounts earned by sexually active khusra prostitutes of other locales. Earnings through traditional occupation of dance can be much more but with minimum surety of being paid and maximum likelihood of being abused, most prefer to earn quick by prostitution. Pooja's take is more or less same with the addition of uninhibited explanation of clientele type-ugly, beautiful, white, and dark-depicting that those involved in prostitution as the only way to earn will yield to any clientele if paid to their likings.

Another respondent articulated as:

Nomi: "First sexual satisfaction, second money. Money is a bonus. They talk bad, high on explicit sexual things, sharing experiences, ways to tap sexual satisfaction, taking drugs, losing control, and engaging in mutual intercourse. All of it raises their lust. For these reasons I prefer to stay alone. I don't mix up with most of them or become part of their gatherings. I am telling you the truth. I fear that I may succumb to their talks. It usually happens, their stories can entice others to do the same which they do. Keeping various girya, keep on standing near road sides, and finding multiple men younger, older, lean, fat, smaller, bigger. . ..."

Nomi's comments are the depiction of socio-sexual settings in which khusras typically function. Dera, peculiarly during evenings when it turns into a meeting point, provides a base for khusras to indulge in sexual talks. Often first author heard them discussing bodily characteristics of their chaamkay (regular clients), pleasure from different sex positions, foreplay techniques which in turn raises the curiosity and excitement of exploring the unexplored. Multiple sexual partners are in part the result of this curiosity and in part of building sexual frustration.

Noori explains her inclination to earn through prostitution as:

"The first time, yes I remember... Some men took advantage of my young age first time. They took me to some shabby hotel, torn my clothes, and then you know what they would have done. I was bleeding and they threw me on a road. I was half naked. It is very common in our line. At school, too, boys used to stop my way and take kisses of me forcibly. I got so upset that I decided not to go to school ever again. After I reached puberty I knew prostitution [pann] to be the only option for me."

Reema also give opinion as:

"A pedophile (londay baaz) keeps an eye on a khusra. He will take him to some place, will give him some pills, do whatever good or bad with him, the result will be that a feminine man will be driven towards prostitution. His body will become receptive to titillation and bodily touch (harkat). Most will become part of deras, he will become she, she will be part of adult gatherings, injecting drugs, drinking alcohol. . . . Her body will become prone to touch. She was innocent just like other kids in her childhood staying with sisters and mothers, hesitating to interact with men. Londay baaz will lure him through attention, food, and money. They may abuse him sexually then he will join us after observing us and our lives."

Noori, a victim of sexual abuse, for a significant period of her life, considered coerced sexual intercourse as the only form of sexual contact a person can have with another person. Repeated sexual abuse, at a young age, shaped her sexuality to the point that after reaching puberty, she started 
working as a professional prostitute. She calls her body a commodity, which yields huge favors to her. She claims of covering each road of Rawalpindi as a cruising site. Another khusra prostitute from Kasur shared that she was repeatedly abused by her father after her mother's death. At the age of 12 , she found the incestuous relationship with her father too complex to grapple with. As a consequence, she ran from her hometown and joined dera commune. Early onset of sexual contacts in the life of a feminized man urges him to be in multiple sexual links with men, which will eventually lead him to earn through prostitution. Reema's explanation of a zenana's body becoming immunized to touch after being sexually abused coupled with alcohol and drug intake will make her more dependent on earnings through prostitution.

The following excerpts explain about he reasons for prostitution:

Masoom: "There are many, what I mean-- Helpless zenanay driven out of their homes abandoned and left out from families. They open deras and sit inside to earn through pann."

Shamshad: "Others are helpless because functions are occasional especially during off seasons. Sometimes wait is too long, after one or two months comes a single function, which may or may not be rewarding. There is always prostitution (pan) when there is no function..."

Reema: "Reason nothing except helplessness. Few are helpless because of their bodily needs, few for money, most are forced into it, beaten up and raped."

Masoom in her remarks states helplessness as the main reason for khusra to prostitute. Helplessness is observed to be due to bodily needs or poverty. Existing literature identifies social isolation as an indicator of prostitution in transgender communities. This research confirms to the existing scholarship on prostitution as many respondents joined dera and hence prostitution after being socially secluded. Shamshad relates helplessness to unavailability of functions compelling zenana to prostitute and Reema relates to both financial and physical needs.

Qaseeda: "Some do it by choice for pleasure, for attention, and for intimacy. Others are immune to it, cannot think of living without it. They go like, "I am a human being, my heart goes in favor of doing it. I can fall in love too." I have been in love with a man, this ongoing year is the ninth one. Sometimes, we fight to the extent that we don't talk. Recently, we had a fight and I am not with him these days, not with anyone nowadays, not a permanent one what I mean to say. Very few of us have life time partners. Most of us claim to have but that is not true. Ask them if they have those partners then why are they prostituting for few money? [pause] Having a special loving, caring, man is extremely rare and if found it's perhaps the most precious thing in our lives. Commitment is rare in these relationships."

Another respondent said:

Nomi: "So it is better maintaing a distance. I have always managed to maintain it. In Lahore, too, I was settled in a dera quite faraway from other deras. I never had to earn through pann, I was fortunate enough to earn through other means. Friendships, I like. They are personal, intimate, and reliable, much more than a few minutes' sexual contacts. Selling body for money, I don't like it. Just for money! That is lame. With money lust mounts."

A fairly recent literature and research is emerging to ask this question: What's love got to do with prostitution? As contradictory as it may sound but studies on South American transgender persons have shown the search of love as the reason for many to enter into prostitution. Studies on Indian hijras have also shown that social discrimination and marginalization leave hijras with minimum chances of social interactions with population outside their communities. In this scenario, forms of economic organisation are the only opportunities left for individual or group interactions with people (men) outside the community. Prostitution being a lucrative occupational choice becomes a hope of finding 'true love of a real man'. Nomi, while alluding to the difference between personalized and de-personalized relationships, thinks she is fortunate for being in a relationship, which to her is intimate than distant and mechanical sex-for-money exchanges. It will be discussed in following sections that money is as instrumental in more personalized relationships as it is in less 
personalized relationships. Qaseeda's depiction starts by hinting towards few khusras who seek for emotional relationships through prostitution, she, then, talks about 'not a permanent one' indicating that she is in temporary relationships for survival and finally juxtaposed the contradictions of those who prostitute inspite being in permanent relationships. The relationships both Nomi and Qaseeda are taking about, though transactional, are 'precious' and 'reliable'. Whereas, in prostitution the interaction is short lived and perfunctory. The following excerpt from a focus group explains the relational dynamics of those who prostitute:

Queen in conversation with the moderator articulated that:

Queen: "Usually they [clients] are quite. It is like when you go to a market you buy something and pay for it. Like a shopkeeper asking for money first then buyer giving price after having satisfied with a product, "Take this money, come on take off your clothes, do it, and go."

Moderator: How much do you earn through panpaisha (prostitution)?

Queen: "It has been a year being part of it. Now I don't have anything to do. I earn just to scrape through, just to bear my daily expenditures. After getting laid whatever clients agree with 100, 200, we carefully spend it. [We] spend hundred and keep the rest for rainy days. You can even check my pockets now I don't have anything."

Seemi: "Money. Yes money, due to money. Our hearts want it to happen just with our special ones, with others it's just for money."

Queen's description of sexual exchange is like an economic exchange, where one party is a seller other a buyer, a seller after being paid gives the commodity (body) to a buyer. Seemi in the next lines marks the difference of money between the sex-for-money exchanges and transactional nature of relationships. To her, people like her, give in sexually to men (who they don't know) to fill financial needs, whereas with 'special ones' they are consensual and money may not be the only drive.

Meenu shared that:

"A person directed me towards prostitution. He observed femininity in me. I used to go to learn embroidery from his center. He showed greater interest in me than other of his students. This is what usually happens. Men approach us with affection and love and since we are so fond of male attention we easily get attracted towards whom after using us leave and we become prone to physical relationships with men. They spend on us, pay us money in exchange of sexual favors. Such relationships fill our emotional appetite, meet our physical needs, fulfill our materialistic wants, and we become habitual."

Meenu's response to the reason on why she prostitutes is perhaps the most comprehensive. Her reply includes almost all the reasons aforementioned. The deceptive self-driven male interests towards zenanas/khusras, their (zenanas) budding likeness towards men, the sexual debuts at early age followed by physical vulnerabilities of getting into multiple sexual contacts, emotional, financial and bodily fulfillness these factors in isolation or in combination are decisive in shaping not just a zenana's sexuality but also her dependence on earning a living through prostitution.

There are varied forms of male-female transgender prostitution with respect to cruising areas, soliciting cites, dera communities and other informal settings. In city Kasur, Steel Bagh Morh and small taverns in Chandini Chowk are the more visited sites for khusra prostitutes. To most, dera communes are the business centers; hence turn out to be the formal socio-sexual place for most clients to seek sexual services. Dera brothels were identified in Gandi Bazaar of Kot Radha Kishan and Babu building of Mansehra. These are just like other dera communes, the rooms of which are rented to other khusra for prostitution. Two khusra friends, despite living with their families, visit their guru's dera at Gandi Bazaar. The two bring clients or clients visit them. The three get ready in the evening waiting for the clients to choose one of the three. Whoever chosen will equally share amongst the three the money earned. The clients are men of age group ranging fifteen to fifty. Most are travellers from the nearby villages and towns, rich or poor urbanites, taxi or truck drivers, landlords, policemen, rowdies, criminals, peons, security guards and students. Respondents in all four locales talk about their preferences, few took pride in saying 'no' to rowdies who were willing to give thousand rupees 
for one time, others preferring to bring into dera or going along with the good looking men only, others preferring money over looks and health-related risks.

Khusras visit cruising cites to find potential clients from where they get picked by cars. They apply heavy make up, wear revealing clothes, cover them with black shawls, and stand near road sides at nights or at the corner of a busy market place or at bus stops, give signals to seemingly interested clients through winking and suggestive hand movements. Men stop their cars, agreeable prices are decided after that they either go with the men, or find some deserted place or to some cheap rented rooms of taverns or hotels. The cruising timings usually start from evening till late night, for those functioning through deras the business hours are from noon till evening. Customers prefer fully dolled up and fearless zenanay who are uninhibited while performing dance or providing sexual services. They can also find potential clients while being at festivals and marriages. Respondents in Mansehra told that after having exchanged mobile numbers they get invitations to which they agree only when the tamashbeen agree on taking them to hotel rooms or homes. This may not hold true for the zenanay of Rawalpindi, most of them think that an open deserted place is apt to escape in case of danger and for quick sexual exchange. At functions, it was observed that interested men zeroed in on zenanay they liked the most, approaching them after the show to take contact numbers. Often they contacted after a day or two to ask for sexual favors, the ones interested would go preferably during the days as winter nights are dark and long in Mansehra. The more informal socio-sexual settings are interactions through friend circles. A zenana would introduce another to her close client who, then, will introduce her to other men. Potential clients are even shared sometimes. For instance, in Handaal Chowk one dera is one door away from another dera. If Raheela (first dera at the start of chowk) sends a cheesa chaamka to Khushboo (fifth dera in a row), then next time Khushboo will send him to Raheela. It wasn't observed in other locales as most want to be laid by good looking men saying "If I won't she will and that too at a lesser price".

The number of clients entertained varies. One respondent used to say 'rozi aye hai' ('a client is here'-rozi is an urdu word meaning earning, in this context a source of earning, a client who is a source, in this case) each time there was a knock at the door. When asked how many clients a zenana usually entertains she replied:

"Mostly ten. Few days are spent alone with no rozi but most of the days there is a

knock at the door after every half an hour."

The time spent is correlated with the amounts paid. The rozi is divided into three groups. First one is a ten minutes rozi who agrees on paying 200 rupees. The next is a twenty minutes rozi who pays four hundred. The ones who offer more than five hundred are thirty (or more) minute's rozi. They are the ones who are high in demand from the community but low in supply from the clientele. The greater the amount the greater will be the pleasure and time allotted. The clients are mostly active males, although few reported of passive clients too, who want from khusra to hide their sexual orientation as passivity in intercourse is stigmatized and strictly forbidden for men.

Pannpaisha (prostitution) as a survival strategy may seem to be lucrative. And it is for many in this field as few respondents earned between fifty thousand to one lac rupees during my fieldwork. In festive seasons, prostitution can be a smart occupational choice to add on to incomes in addition to dance and dhinga. But once season is off, the earnings will fall considerably. There is no such real stability to the earnings. Social discrimination and isolation further bottlenecks already-stigmatized ways to earn a living for the khusras.

\section{CONCLUSION}

The current research has explored various forms of economic organization of khusra communities residing in four different locales of Pakistan. These forms are neither economically rewarding nor stable. As explained in the preceding text, the forms of bidhae, jorha, tola bazar, dance functions and prostitution depict marginalization of khusra community. On the other hand, as a result of lack of livelihood options, whatever options available to khusras further stigmatize the community primarily because of the fact that their major source of income is prostitution. Qualitative research methods have helped in understanding the communal dynamics of socio-economic organization of the khusra community and in deciphering the layered narratives of structural discrimination, and paucity of 
livelihood options. The forms of economic organization are seasonal, momentary, unstable and risky. Some are inter-generational such as bidhaee, jorha and tola bazar, hence are considered respectful despite being least monetarily rewarding, time consuming and laborious, whereas panpaisha despite yielding quick-money and less-laborious is not considered a respected form of earning money. Although most of the narratives from respondents narrate that resorting to panpaisha is inevitable for khusras. Some forms such as dance functions require greater physical, artistic and communication skills than other forms. However, all forms, as stated by respondents, detail incidents of physical abuse and/or sexual violence. These form also build relational dynamics among khusras and the wider population such as with clients for those who are into prostitution. These relations can be short- or long-termed depending upon whether the relation has turned into a reciprocal or an emotive one or not. The reasons for resorting to these different forms are also quoted by respondents ranging from poverty, sexual proclivity, communal conditioning or inter-generational pre-requisites.

\section{ACKNOWLEDGMENTS}

We wish to thank all the respondents who agreed to take part in the current research. A special mention goes to the key informants who helped in providing valuable information and in easing our access to the community members. We are also thankful to the anonymous reviewers for their timely reviews on multiple drafts.

\section{REFERENCES}

Abdullah, M. A., Basharat, Z., Kamal, B., Sattar, N. Y., Hassan, Z. F., Jan, A. D., \& Shafqat, A. (2012). Is social exclusion pushing the Pakistani hijras (transgenders) towards commercial sex work? A qualitative study. BMC International Health and Human Rights, 12(32), 32-40.

Kuggle, S. S. A. (2010). Reforming Shari'a: Islamic Ethics of same-sex marriages. Homosexuality in Islam - Critical Reflection on Gay, Lesbian, and Transgender Muslims, Al-Haqq Kugle, Scott, Siraj. Oneworld Publications.

Berg, B. L. (2001). Qualitative research methods for the social sciences. Pearson Education Company.

Caceres, C. F., Aggleton, P., \& Jerome, T. G. (2008). Sexual diversity, social inclusion and HIV/AIDS. AIDS, 22(2), 45-55.

Gaskell, G. (2000). Individual and group interviewing. Qualitative researching with text, image and sound, W. Bauer, Martin. and Gaskell, George. SAGE.

Khan, A. A., \& Khan, A. (2010). The HIV epidemic in Pakistan. Journal of Pakistan Medical Association, 60(4), 300-307.

Khan, S. (1999). Through a window darkly: Men who sell sex to men in India and Bangladesh. Men who sell sex: International perspectives on male prostitution and HIV/AIDS, Aggleton, Peter. Routledge.

Khan, S. I., Hussain, M. I., Parveen, S., Bhuiyan, M. I., Gourab, G., Sarker, G. F., Arafat, S. M., \& Sider, J. (2009). Living on the extreme margin: Social Exclusion of the Transgender Population (Hijra) in Bangladesh. Journal of Health, Population and Nutrition, 27(4), 441451.

Nanda, S. (1999). Neither man nor woman: The hijras of India. Wadsworth Publishing.

Naqvi, N. \& Mujtaba, H. (1997). Two Baluchi Buggas, a Sindi Zenana, and the status of Hijras in contemporary Pakistan. Islamic Homosexualities: Culture, History, and Literature, Murray, SO. NYU Press.

Reddy, G. (2005). With respect to sex: Negotiating hijra identity in South India. University of Chicago Press.

Ritchie, J. \& Lewis, J. (2003). Qualitative research practice: A guide for social science students and researchers. SAGE Publications.

\footnotetext{
${ }^{\mathrm{i}}$ Defined with respect to community as to what they mean what a Dera is.

${ }^{\text {ii }}$ Fictitious names have been used in the write-up.
} 